\title{
DIE INVLOED VAN DOELWITSTELLING OP PRESTASIE
}

J.G.A. LOUW ${ }^{*}$

OKIEP KOPERMAATSKAPPY
A.S. ENGELBRECHT

DEPARTEMENT BEDRYFSIELKUNDE

UNIVERSITEIT VAN STELLENBOSCH

\section{ABSTRACT}

Although a number of research studies support Locke's goalsetting theory, conflicting results are encountered in the Literature which suggest further investigation into the subtleties of the theory. The results of this study indicate that an increase in goal-difficulty does not always lead to a corresponding increase in performance. The latter could also not be explained in terms of the degree of goal-acceptance as an intervening variable. It was found that financial incentives and the way in which a nonspecific goal is formulated could have a significant effect on performance. Recommendations are made for future research.

Volgens Mento, Cartledge en Locke (1980) is die twee mees invloedryke hedendaagse motiveringsteorieë die verwagtingsteorie en die doelwitstellingsteorie. Alhoewel die teorie van doelwitstelling 'n groot mate van ooreenstemming met doelwitbestuur ("management by objectives") toon, het die twee benaderings uit duidelik uiteenlopende ontwikkelingsbane ontstaan. In hierdie verband stel Miner (1980) dit duidelik dat doelwitbestuur die meer onlangse en mees gevorderde formulering van die doelwitstellingsteorie 'n aantal jare voorafgegaan het. Verskeie skrywers (Steers en Porter, 1974; Miner, 1980; Luthans, 1981) is van mening dat die duidelikste vorm van organisatoriese toepassing van die onderliggende beginsels van die doelwitstellingsteorie in die konsep van doelwitbestuur geleë is.

Op grond van die resultate van 'n reeks eksperimente deur Locke en sy medewerkers publiseer Locke in 1968 'n artikel wat allerweë as die standaardwerk op die gebied van die teorie van doelwitstelling beskou word (Luthans, 1981). Die belangrikste aspekte van hierdie teorie (Locke, 1968) sien soos volg daaruit:

- $\quad$ Hoe moeiliker die doelwit, hoe hoër sal die vlak van prestasie wees. Dit is egter slegs die geval indien die doelwit deur die individu aanvaar word.

\footnotetext{
${ }^{*}$ Versoeke vir afskrifte moet aan die eerste skrywer gerig word
} 
- $\quad$ Individue met spesifieke doelwitte sal beter presteer as diegene met nie-spesifieke doelwitte.

- Finansiële aansporings, gekoppel aan doelwitstelling, het geen onafhanklike invloed op prestasie nie. Die invloed wat finansiële aansporings op prestasie kan hê, is geheel en al aan doelwitstellingsfaktore toe te skryf. Finansiële aansporings kan wel veroorsaak dat individue doelwitte aanvaar en doelwitte stel wat hulle andersins nie sou gedoen het nie.

Uit die literatuuroorsigte van Steers en Porter (1974), Latham en Yukl (1975) en Locke, Shaw, Saari en Latham (1981) blyk dit dat die oorgrote meerderheid van studies bevind het dat moeilike doelwitte tot beduidend hoër prestasie aanleiding gee as maklike doelwitte. Net so het die meerderheid van studies getoon dat persone met spesifieke doelwitte beduidend beter presteer as diegene met nie-spesifieke doelwitte.

Frost en Mahoney (1976) het egter gevind dat 'n toename in die moeilikheidsgraad van doelwitte nie altyd tot 'n beduidende toename in prestasie lei nie. Hierdie resultate kon ook nie op grond van 'n gebrek aan doelwitaanvaarding verklaar word nie. Die invloed van doelwitmoeilikheidsgraad op prestasie, asook die verband tussen prestasie en doelwitaanvaarding, regverdig dus verdere navorsing.

Die tipe nie-spesifieke doelwit wat Locke en sy medewerkers (Locke en Bryan, 1967) gebruik het, word ook deur Frost en Mahoney (1976) bevraagteken. Locke en sy medewerkers het die instruksie van "doen julle beste" as 'n nie-spesifieke doelwit beskou. Frost en Mahoney (1976) is egter van mening dat sodanige doelwit 'n verwarrende invloed op die proefpersone kan hê, aangesien doelwitmoeilikheidsgraad daardeur geïmpliseer word. Hulle verkies dan ook die instruksie van "werk totdat julle gevra word om te stop" as 'n nie-spesifieke doelwit. Geen studie kon egter in die literatuur gevind word wat ondersoek na die verskille in prestasie op grond van hierdie twee nie-spesifieke doelwitte ingestel het nie. Die moontlike verskil in prestasie wat hierdie twee tipes nie-spesifieke doelwitte tot gevolg kan hê, regverdig ook verdere navorsing.

Studies deur Pritchard en Curts (1973) en Rosswork (1977) het gevind dat groot finansiële aansporings wel 'n beduidend onafhanklike invloed op prestasie kan hê, wat in teenstelling met die bevindings van Locke, Bryan en Kendall (1968) is. Dit blyk dus dat verdere navorsing ten opsigte van die invloed van finansiële aansporings, gekoppel aan doelwitstelling, noodsaaklik is. 
In die lig van bogenoemde leemtes in navorsing oor doelwitstelling is daar in hierdie studie probeer bepaal of ' $n$ toename in die moeilikheidsgraad van doelwitte tot ' $n$ toename in prestasie sal lei en indien nie, of hierdie bevindings aan 'n gebrek aan doelwitaanvaarding toegeskryf kan word. Ook is probeer bepaal of daar 'n beduidende verskil tussen die prestasie van persone met doelwitte van verskillende spesifiekheidsgrade bestaan. Die invloed van finansiële aansporings op prestasie en doelwitaanvaarding is ook ondersoek.

METODE

\section{Hipoteses}

Die volgende nulhipoteses is vir die doeleindes van hierdie studie gestel:

$\mathrm{H}_{1}$ : Daar bestaan geen beduidende verskille tussen die prestasies van persone met die volgende doelwitmoeilikheidsgrade nie:
(a) Baie maklike doelwit
(b) Redelik maklike doelwit
(c) Redelik moeilike doelwit
(d) Baie moeilike doelwit

$\mathrm{H}_{2}$ : Daar bestaan geen beduidende verskil tussen die doelwitaanvaarding van persone met die volgende doelwitmoeilikheidsgrade nie:
(a) Baie maklike doelwit
(b) Redelik maklike doelwit
(c) Redelik moeilike doelwit
(d) Baie moeilike doelwit

$\mathrm{H}_{3}$ : Daar bestaan geen beduidende verband tussen die prestasie en doelwitaanvaarding van persone met die volgende doelwitmoeilikheidsgrade nie:
(a) Baie maklike doelwit
(b) Redelik maklike doelwit
(c) Redelik moeilike doelwit
(d) Baie moeilike doelwit

$\mathrm{H}_{4}$ : Daar bestaan geen beduidende verskil tussen die prestasie van persone met die volgende doelwitspesifiekheidsgrade nie:

(a) Geen doelwit

(b) Nie-spesifieke doelwit 
(c) Spesifieke doelwit

$\mathrm{H}_{5}$ : Daar bestaan geen beduidende verskil tussen die prestasie van persone met dieselfde doelwitmoeilikheidsgraad, maar met die volgende finansiële aansporings nie:

(a) Geen finansiële aansporing

(b) Klein finansiële aansporing

(c) Groot finansiële aansporing

$\mathrm{H}_{6}$ : Daar bestaan geen beduidende verskil tussen die doelwitaanvaarding van persone met dieselfde doelwitmoeilikheidsgraad, maar met die volgende finansiële aansporings nie;

(a) Geen finansiële aansporing

(b) Klein finansiële aansporing

(c) Groot finansiële aansporing

Ten opsigte van elk van bogenoemde nulhipoteses is die alternatiewe hipotese gestel dat daar wel ' $n$ beduidende verskil of beduidende verband bestaan.

\section{Meetmiddels}

Aard en administrasie van die taak. Vir die doeleindes van hierdie ondersoek is 'n laboratoriumeksperiment uitgevoer. Om die nodige gegewens vir die uitvoering van hierdie studie te bekom, is 'n self-gekonstrueerde taak gebruik wat deur die proefpersone verrig moes word. Hierdie taak bestaan uit die sommering van drie tweesyfergetalle. Dieselfde tipe taak is onder andere deur Locke en Bryan (1967) in hulle studies gebruik.

Die verskillende groepe proefpersone is na verskillende lokale vir die uitvoering van die take geneem. In elkeen van die verskillende lokale was daar twee toetsafnemers. Hierdie toetsafnemers het die instruksies van die take saam met die proefpersone deurgelees. Nadat daar verseker is dat alle proefpersone verstaan wat van hulle verwag word, is hulle opdrag gegee om met die uitvoering van die taak te begin. Nadat 'n periode van 10 minute verstryk het, is die proefpersone gevra om te stop en is die voltooide take ingeneem.

Onafhanklike veranderlikes. Vir die doeleindes van hierdie studie was dit nodig om drie tipes onafhanklike veranderlikes te spesifiseer: Die moeilikheidsgraad van die doelwitte, die spesifiekheidsgraad van die doelwitte en die grootte van die finansiële aansporings wat aan 'n sekere doelwit gekoppel is. 
Frost en Mahoney (1976) definieer doelwitmoeilikheidsgraad as die objektiewe waarskynlikheid dat 'n gegewe doelwitvlak wel bereikbaar is. Die vier verskillende moeilikheidsgrade in hierdie studie is bepaal deurdat 'n loodsstudie op 'n groep Bedryfsielkundestudente $(\mathrm{n}=36)$ gedoen is. Hierdie persone het almal dieselfde instruksies ontvang, naamlik om teen 'n normale tempo te werk totdat hulle gevra word om te stop. Hierdie prosedure is in ooreenstemming met die wat deur Frost en Mahoney (1976) gevolg is.

Die gemiddelde aantal korrekte oplossings in 'n 10 minute periode vir bogenoemde groep was 78 . Hierdie gemiddelde telling is afgerond tot 80 , wat as 'n redelike maklike doelwit beskou is. Die ander drie moeilikheidsgrade is persentasiegewys van die redelike maklike doelwit, wat as standaard gebruik is, afgelei:

$$
\begin{array}{ll}
\text { baie maklik } & =50 \% \times 80=40 \\
\text { redelik maklik } & =100 \% \times 80=80(\text { standaard }) \\
\text { redelik moeilik } & =150 \% \times 80=120 \\
\text { baie moeilik } & =200 \% \times 80=160
\end{array}
$$

Doelwitspesifiekheid word deur Frost en Mahoney (1976) gedefinieer as die mate waartoe doelwitvlakke op 'n gekwantifiseerde eerder as op 'n vae manier (byvoorbeeld "werk totdat u gevra word om te stop") gestel word. In hierdie studie is daar van twee tipes niespesifieke doelwitte gebruik gemaak. Die een groep persone is bloot meegedeel om te werk totdat hulle gevra word om te stop (geen doelwit), terwyl die ander groep die instruksie ontvang het om hulle beste te doen en te kyk hoeveel van die probleme hulle in 'n 10 minute periode kan voltooi (nie-spesifieke doelwit). Verder is die redelike moeilike doelwit van 120 korrekte oplossings as 'n spesifieke doelwit vir die doeleindes van hierdie studie beskou. Bogenoemde grade van doelwitspesifiekheid is in ooreenstemming met dié wat deur Locke en Bryan (1967) en Frost en Mahoney (1976) gebruik is.

Die grootte van die finansiële aansporings wat aan doelwitbereiking gekoppel is, is op 'n blote arbitrêre wyse gekies. ' $n$ Beloning van $R 1,00$ is as 'n klein finansiële aansporing en 'n $\mathrm{R} 10,00$ beloning as ' $\mathrm{n}$ groot finansiële aansporing beskou. Beide hierdie belonings is aan ' $\mathrm{n}$ doelwit van 120 probleme gekoppel.

Om 'n verdere aanduiding van die invloed van finansiële aansporings op prestasie en doelwitaanvaarding te verkry, is hierdie twee beloningsgroepe met 'n derde groep vergelyk wat dieselfde doelwitmoeilikheidsgraad gehad het. Laasgenoemde groep het egter geen finansiële aansporings ontvang nie. 
Afhanklike veranderlikes. Die afhanklike veranderlikes wat in hierdie ondersoek gemeet is, is die prestasie van die proefpersone en die mate van doelwitaanvaarding wat deur hulle getoon is.

Prestasie is in terme van die aantal probleme wat korrek opgelos is, gemeet. 'n Soortgelyke prosedure is deur Locke en Bryan (1967) gevolg.

Frost en Mahoney (1976) definieer doelwitaanvaarding as 'n bereidwilligheid om 'n genoegsame poging aan te wend om 'n doelwit te bereik. In hierdie studie is doelwitaanvaarding deur middel van 'n twee-item vraelys gemeet. 'n Soortgelyke vraelys is deur Frost en Mahoney (1976) gebruik (Kyk Louw, 1983 vir nadere besonderhede).

Proefpersone. Die monster wat in hierdie ondersoek gebruik is, het bestaan uit 272 Bedryfsielkunde 1-studente aan die Universiteit van Stellenbosch. Daar is probeer om hierdie proefpersone op 'n toevallige wyse aan die 8 eksperimentele groepe toe te deel.

\section{RESULTATE}

Die gemiddelde prestasie en doelwitaanvaarding van die verskillende groepe, asook die standaardafwykings word in Tabel 1 aangetoon.

\section{$\underline{\text { TABEL } 1}$}

\section{GEMIDDELDE PRESTASIE EN DOELWITAANVAARDING VAN DIE EKSPERIMENTELE GROEPE}

\begin{tabular}{llccc}
\hline VERANDERLIKE & \multicolumn{1}{c}{ GROEP } & $\mathrm{n}$ & $\bar{X}$ & $\mathrm{~s}$ \\
\hline Prestasie & Baie maklike doelwit & 40 & 82,13 & 17,97 \\
& Redelik maklike doelwit & 28 & 88,32 & 21,37 \\
& Redelik moeilike doelwit & 39 & 85,74 & 22,44 \\
& Baie moeilike doelwit & 29 & 86,00 & 14,88 \\
\hline Doelwitaanvaarding & Baie maklike doelwit & 40 & 7,68 & 1,67 \\
& Redelik maklike doelwit & 28 & 7,29 & 1,58 \\
& Redelik moeilike doelwit & 39 & 7,00 & 1,57 \\
& Baie moeilike doelwit & 29 & 6,79 & 1,54 \\
\hline Prestasie & Geen doelwit & 36 & 80,86 & 19,58 \\
& Nie-spesifieke doelwit & 39 & 87,76 & 26,81 \\
& Spesifieke doelwit & 33 & 85,74 & 22,44 \\
\hline Prestasie & Geen finansiële aansporing & 39 & 85,74 & 22,44 \\
& Klein finansiële aansporing & 34 & 82,68 & 20,19 \\
& Groot finansiële aansporing & 33 & 91,00 & 26,28 \\
\hline Doelwitaanvaarding & Geen finansiële aansporing & 39 & 7,00 & 1,57 \\
& Klein finansiële aansporing & 34 & 6,56 & 1,28 \\
& Groot finansiële aansporing & 33 & 6,88 & 2,18 \\
\hline
\end{tabular}


Die invloed van doelwitmoeilikheidsgraad op prestasie en doelwitaanvaarding

Uit Tabel 1 blyk dit dat die groep met die redelik maklike doelwit die hoogste gemiddelde prestasie behaal het. Die maklike doelwitgroep het soos verwag die laagste presteer. Hierdie resultate word in Figuur 1 voorgestel.

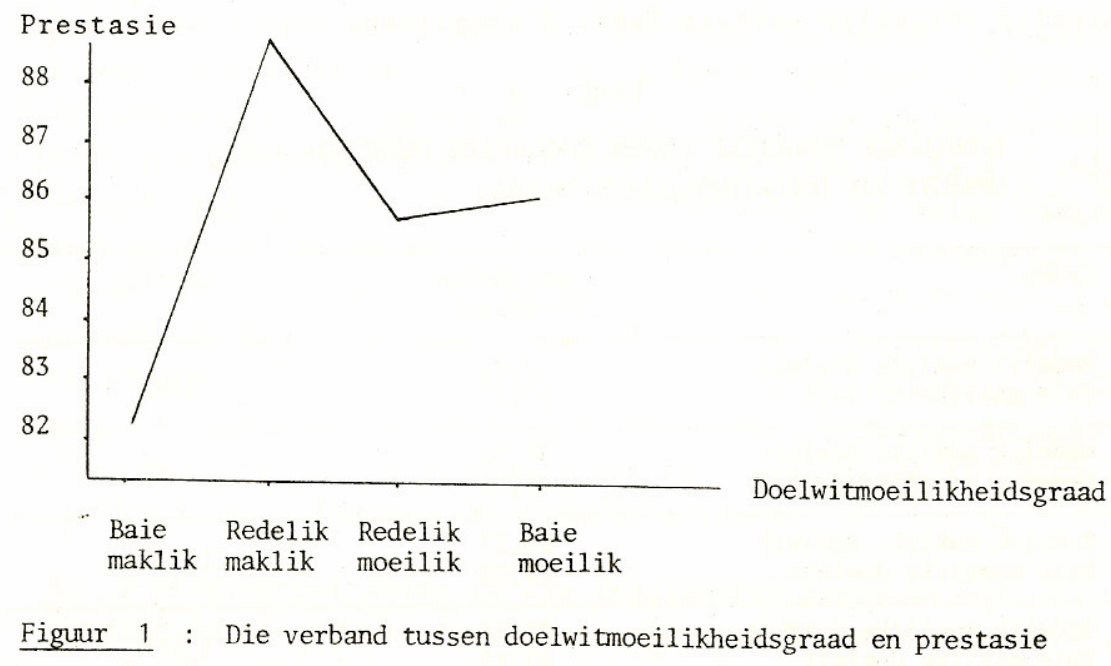

Om egter meer betekenisvolle afleidings te kan maak, is die gegewens aan 'n eenrigting variansie-ontleding onderwerp. Die resultate van hierdie ontleding dui daarop dat daar wel 'n beduidende verskil $(\mathrm{F}(3,132)=665,62, \mathrm{p}<, 001)$ tussen die gemiddelde prestasie van persone met doelwitte van verskillende moeilikheidsgrade bestaan. Alternatiewe hipotese 1, naamlik dat daar 'n beduidende verskil in die prestasie van persone met doelwitte van verskillende moeilikheidsgrade bestaan, kan dus nie verwerp word nie.

Daar kan egter nog nie afgelei word tussen watter groepe daar beduidende verskille in gemiddelde prestasie bestaan nie. Die Scheffé-metode van meervoudige vergelykings (Du Toit, 1975) is gevolglik op hierdie gegewens toegepas. Daar is gevind dat al die groepsgemiddeldes beduidend $(\mathrm{p}<, 01)$ van mekaar verskil. Hierdie verskille word in Tabel 2 aangetoon. 
TABEL 2

\section{BEDUIDENDE VERSKILLE TUSSEN GEMIDDELDE PRESTASIE TEN OPSIGTE VAN DOELWITMOEILIKHEIDSGRAAD}

\begin{tabular}{lcc}
\hline Groep & Gemiddelde prestasie & Verskil \\
\hline Redelik maklike doelwit & 88,32 & $6,19^{*}$ \\
Baie maklike doelwit & 82,13 & \\
\hline Redelik maklike doelwit & 88,32 & $2,58^{*}$ \\
Redelik moeilike doelwit & 85,74 & \\
\hline Redelik maklike doelwit & 88,32 & $2,32^{*}$ \\
Baie moeilike doelwit & 86,00 & \\
\hline Redelik moeilike doelwit & 85,74 & $3,61^{*}$ \\
Baie maklike doelwit & 82,13 & \\
\hline Baie moeilike doelwit & 86,00 & \\
Redelik moeilike doelwit & 85,74 & $3,87^{*}$ \\
\hline Baie moeilike doelwit & 86,00 & \\
Baie maklike doelwit & 82,13 & \\
\hline
\end{tabular}

Die gegewens in Tabel 2 toon aan dat die redelik maklike doelwitgroep beduidend beter as al die ander doelwitgroepe presteer het. Verder het die baie moeilike doelwitgroep beduidend beter as die baie maklike en redelik moeilike doelwitgroepe presteer, terwyl die redelik moeilike doelwitgroep ook beduidend beter as die baie maklike doelwitgroep presteer het.

Uit Tabel 1 blyk dit verder dat die mate van doelwitaanvaarding afneem in reaksie op 'n toename in die moeilikheidsgraad van die doelwitte. Om te bepaal of die gemiddelde doelwitaanvaarding van die groepe beduidend van mekaar verskil, is die ingesamelde gegewens aan 'n eenrigting variansie-ontleding onderwerp. Dit blyk uit die resultate van hierdie ontleding dat daar ' $\mathrm{n}$ beduidende verskil $(\mathrm{F}(3,132)=672,78, \mathrm{p}<, 001)$ tussen die gemiddelde doelwitaanvaarding van groepe met doelwitte van verskillende moeilikheidsgrade is. Alternatiewe hipotese 2, naamlik dat daar 'n beduidende verskil tussen die doelwitaanvaarding van persone met doelwitte van verskillende moeilikheidsgrade bestaan, kan dus nie verwerp word nie.

As ' $n$ verdere ontleding is die ingesamelde gegewens aan die Scheffé-metode van meervoudige vergelykings onderwerp. Dit is gedoen om te bepaal tussen watter groepe daar beduidende verskille in doelwitaanvaarding bestaan. Die resultate van hierdie vergelykings word in Tabel 3 aangetoon. 
Dit blyk duidelik uit Tabel 3 dat doelwitaanvaarding beduidend afneem soos die moeilikheidsgraad van die doelwitte toeneem. Hierdie verskynsel is moontlik toeskryfbaar aan die feit dat die persone se waarnemings van hulle eie vermoëns om die doelwit te bereik, en dus ook hulle verwagtings ten opsigte van doelwitbereiking, afneem in ooreenstemming met 'n toename in doelwitmoeilikheidsgraad.

\section{$\underline{\text { TABEL } 3}$}

\section{BEDUIDENDE VERSKILLE TUSSEN GEMIDDELDE DOELWITAANVAARDING TEN OPSIGTE VAN DOELWITMOEILIKHEIDSGRAAD}

\begin{tabular}{lcc}
\hline Groep & $\begin{array}{c}\text { Gemiddelde } \\
\text { doelwitaanvaarding }\end{array}$ & Verskil \\
\hline Baie maklike doelwit & 7,68 & $0,39^{*}$ \\
Redelik maklike doelwit & 7,29 & $0,68^{*}$ \\
\hline Baie maklike doelwit & 7,68 & \\
Redelik moeilike doelwit & 7,00 & $0,89^{*}$ \\
\hline Baie maklike doelwit & 7,68 & $0,29^{*}$ \\
Baie moeilike doelwit & 6,79 & $0,50^{*}$ \\
\hline Redelik maklike doelwit & 7,29 & \\
Redelik moeilike doelwit & 7,00 & $0,21^{*}$ \\
\hline Redelik maklike doelwit & 7,29 & \\
Baie moeilike doelwit & 6,79 & \\
\hline Redelik moeilike doelwit & 7,00 & 6,79 \\
Baie moeilike doelwit & &
\end{tabular}

$* p<0,01$

Die korrelasies tussen doelwitaanvaarding en prestasie vir die verskillende groepe word in Tabe1 4 aangetoon.

\section{TABEL 4}

\section{KORRELASIES TUSSEN DOELWITAANVAARDING EN PRESTASIE}

\begin{tabular}{lll}
\hline Groep & $\mathrm{n}$ & $\mathrm{r}$ \\
\hline Baie maklike doe1wit & 40 &, $94^{*}$ \\
Rede1ik mak1ike doelwit & 28 &, $95^{*}$ \\
Rede1ik moeilike doe1wit & 39 &, $97^{*}$ \\
Baie moei1ike doe1wit & 29 &, $96^{*}$ \\
\hline
\end{tabular}

$* \mathrm{p}<0,001$

Die korrelasies in Tabel 4 toon aan dat daar 'n hoë beduidend positiewe verband tussen die doelwitaanvaarding en prestasie van al die groepe bestaan. In die lig van hierdie resultate 
kan alternatiewe hipotese 3, naamlik dat daar 'n beduidende verband tussen doelwitaanvaarding en prestasie bestaan, nie verwerp word nie.

In die lig van bogenoemde bevindings blyk dit dus dat Locke (1968) se teorie van 'n toenemend liniêre verband tussen doelwitmoeilikheidsgraad en prestasie nie aanvaar kan word nie. Volgens hom beteken dit dus dat hoe moeiliker die doelwit is, hoe hoër is die prestasie, tot en met uitsonderlike hoë doelwitte. Hierdie nie-ondersteunende resultate kan ook nie op grond van 'n gebrek aan doelwitaanvaarding verk1aar word nie. So is daar byvoorbeeld gevind dat alhoewel die baie maklike doelwitgroep beduidend swakker as die redelike moeilike en baie moeilike doelwitgroepe presteer het, eersgenoemde groep nogtans 'n beduidend hoër mate van doelwitaanvaarding as laasgenoemde twee groepe getoon het.

Bogenoemde gevolgtrekking is in ooreenstemming met die resultate van 'n studie deur Frost en Mahoney (1976). Hulle kon ook nie 'n daling in prestasie op grond van 'n gebrek aan doelwitaanvaarding verklaar nie.

Die resultate van hierdie studie bied verder gedeeltelike ondersteuning aan die siening van Atkinson (Locke, 1968). Atkinson is " $n$ voorstaander van 'n klokvormige verband tussen doelwitmoeilikheidsgraad en prestasie. Hy huldig die standpunt dat poging en die daaropvolgende prestasie 'n maksimum is indien daar 'n $50 \%$ kans op sukses bestaan om die doelwit te bereik. Indien die waarskynlikheid van suksesvolle doelwitbereiking egter minder as $50 \%$ is, sal daar ' $n$ afname in die hoeveelheid poging en prestasie plaasvind. Soos blyk uit Figuur 1 is daar in hierdie studie ook 'n neiging tot 'n klokvormige verband gevind, behalwe in die geval van die baie moeilike doelwitgroep. Hierdie groep het beduidend beter as die redelik moeilike doelwitgroep presteer.

Die resultate van hierdie studie verleen dus geen algehele ondersteuning aan óf die siening van Locke óf die siening van Atkinson ten opsigte van die verwantskap tussen doelwitmoeilikheidsgraad en prestasie nie.

\section{Die invloed van doelwitspesifiekheid op prestasie}

Dit blyk uit Tabel 1 dat die groep sonder 'n doelwit gemiddeld swakker as die ander twee groepe presteer het. Die groep met die nie-spesifieke doelwit het egter gemiddeld beter as die groep met die spesifieke doelwit presteer. Ten einde meer betekenisvolle afleidings te kan maak, is die ingesamelde gegewens aan 'n eenrigting variansie-ontleding onderwerp. Daar is gevind dat daar 'n beduidende verskil $(F(2,105)=614,25, p<, 001)$ tussen die gemiddelde 
prestasie van groepe met doelwitte wat wissel in spesifiekheid bestaan. Hierdie ontleding toon dus dat alternatiewe hipotese 4 , naamlik dat daar 'n beduidende verskil in die prestasie van persone met doelwitte van verskillende spesifiekheidsgrade bestaan, nie verwerp kan word nie.

Uit die resultate van die variansie-ontleding kan egter nie afgelei word tussen watter groepe daar wel beduidende verskille in prestasie bestaan nie. Die Scheffé-metode van meervoudige vergelykings is gevolglik op die gegewens toegepas. Daar is gevind dat al die groepsgemiddeldes beduidend $(\mathrm{p}<, 01)$ van mekaar verskil. Hierdie verskille word in Tabel 5 aangetoon.

\section{$\underline{\text { TABEL } 5}$}

BEDUIDENDE VERSKILLE TUSSEN GEMIDDELDE PRESTASIE TEN OPSIGTE VAN DOELWITSPESIFIEKHEIDSGRAAD

\begin{tabular}{lcc}
\hline Groep & Gemiddelde prestasie & Verskil \\
\hline Nie-spesifieke doelwit & 87,76 & $6,90^{*}$ \\
Geen doelwit & 80,86 & \\
\hline Nie-spesifieke doelwit & 87,76 & $2,02^{*}$ \\
Spesifieke doelwit & 85,74 & \\
\hline Spesifieke doelwit & 85,74 & $4,88^{*}$ \\
Geen doelwit & 80,86 & \\
\hline$* \mathrm{p}<0,01$ & &
\end{tabular}

Die gegewens in Tabel 5 toon dat die nie-spesifieke doelwitgroep ("doen julle beste") beduidend beter as die groepe met onderskeidelik geen ("werk totdat julle gevra word om te stop") en spesifieke ("doen 120 probleme") doelwitte presteer het. Persone met 'n spesifieke doelwit het wel beduidend beter presteer as diegene met geen doelwit nie.

Bogenoemde resultate dui dus daarop dat die manier waarop 'n nie-spesifieke doelwit geformuleer word, 'n beduidende invloed op die prestasie van die proefpersone kan he. Dit wil voorkom asof die instruksie van "doen julle beste" 'n kontaminerende invloed op doelwitstellingsresultate kan hê, wat in ooreenstemming met die siening van Frost en Mahoney (1976) is. Frost en Mahoney (1976) voer aan dat doelwitmoeilikheid deur 'n instruksie soos "doen julle beste" geïmpliseer kan word. Dit kan verwarring oor die werklike betekenis van die doelwit by die proefpersone veroorsaak. Hulle verkies dan ook dat ' $n$ instruksie soos "werk totdat julle gevra word om te stop" eerder as "doen julle beste" as 'n nie-spesifieke doelwit gebruik word. 
Uit die resultate in Tabel 1 blyk dit verder dat groot finansiële aansporings daartoe lei dat persone beter presteer as wanneer daar geen of klein finansiële aansporings verskaf word. Klein finansiële aansporings het blykbaar geen positiewe invloed op prestasie nie.

Om te bepaal of die gemiddelde prestasie van hierdie drie groepe beduidend van mekaar verskil, is 'n eenrigting variansieontleding gedoen. Uit hierdie ontleding blyk dit dat daar ' $\mathrm{n}$ beduidende verskil $(\mathrm{F}(2,103)=487,61, \mathrm{p}<, 001)$ tussen die gemiddelde prestasie van groepe met verskillende finansiële aansporings bestaan. Alternatiewe hipotese 5, naamlik dat finansiële aansporings, gekoppel aan doelwitte, aanleiding tot beduidende verskille in prestasie gee, kan dus nie verwerp word nie.

As ' $n$ verdere ontleding is die gegewens aan die Scheffé-metode van meervoudige vergelykings onderwerp. Dit is gedoen om te bepaal tussen watter groepgemiddeldes daar beduidende verskille bestaan. Die resultate van hierdie vergelykings word in Tabel 6 aangetoon.

\section{$\underline{\text { TABEL } 6}$}

\section{BEDUIDENDE VERSKILLE TUSSEN DIE GEMIDDELDE PRESTASIE VAN GROEPE MET VERSKILLENDE FINANSIËLE AANSPORINGS}

\begin{tabular}{lcc}
\hline Groep & Gemiddelde prestasie & Verskil \\
\hline Geen finansiële aansporing & 85,74 & $3,1^{*}$ \\
Klein finansiële aansporing & 82,68 & \\
\hline Groot finansiële aansporing & 91,00 & $5,26^{*}$ \\
Geen finansiële aansporing & 85,74 & \\
\hline Groot finansiële aansporing & 91,00 & $8,32^{*}$ \\
Klein finansiële aansporing & 82,68 & \\
\hline $\mathrm{p}<0,01$ & &
\end{tabular}

Die resultate in Tabel 6 toon dat persone met groot finansiële aansporings beduidend beter as persone met geen of klein finansiële aansporings presteer. Klein finansiële aansporings het egter nie beduidend beter prestasie as geen finansiële aansporings tot gevolg nie.

Dit blyk dus dat groot finansiële aansporings wel 'n onafhanklike invloed op prestasie kan hê. Hierdie resultate is in teenstelling met die siening van Locke (1968) en Locke, et al., (1968) wat aanvoer dat finansiële aansporings geen onafhanklike invloed op prestasie het nie. Pritchard en Curts (1973) is egter van mening dat Locke, et al., (1968) van te klein finansiële 
aansporings gebruik gemaak het in hulle studie en dat groot finansiële aansporings wel 'n beduidend onafhanklike invloed op prestasie kan hê. Die resultate van hierdie studie is dan ook ondersteunend tot hierdie siening van Pritchard en Curts (1973). Dit wil verder blyk asof die klein finansiële aansporing 'n demotiverende invloed op die proefpersone gehad het. As gevolg daarvan het die groep met die klein finansiële aansporing beduidend swakker as die groep sonder enige finansiële aansporing presteer.

\section{Die invloed van finansiële aansporings op doelwitaanvaarding}

Die gegewens in Tabel 1 toon aan dat daar wel verskille in doelwitaanvaarding tussen groepe met verskillende finansiële aansporings bestaan. Om te bepaal of hierdie verskille beduidend is, is ' $\mathrm{n}$ eenrigting variansie-ontleding uitgevoer. Dit blyk dat daar wel 'n beduidende verskil $(\mathrm{F}(2,103)=661,77, \mathrm{p}<, 001)$ tussen die gemiddelde doelwitaanvaarding van groepe met verskillende finansiële aansporings is. Op grond van hierdie bevindings kan alternatiewe hipotese 6, naamlik dat finansiële aansporings, gekoppel aan doelwitte, aanleiding tot beduidende verskille in doelwitaanvaarding gee, nie verwerp word nie.

Ten einde te bepaal tussen watter groepsgemiddeldes daar beduidende verskille bestaan, is die Scheffé-metode van meervoudige vergelykings gedoen. Die resultate van hierdie vergelykings word in Tabel 7 aangetoon.

\section{TABEL 7}

\section{BEDUIDENDE VERSKILLE TUSSEN DIE GEMIDDELDE DOELWITAANVAARDING VAN GROEPE MET VERSKILLENDE FINANSIËLE AANSPORINGS}

\begin{tabular}{lcc}
\hline \multicolumn{1}{c}{ Groep } & Gemiddelde prestasie & Verskil \\
\hline Geen finansiële aansporings & 7,00 & $0,44^{*}$ \\
Klein finansiële aansporings & 6,56 & \\
\hline Geen finansiële aansporings & 7,00 & $0,12^{*}$ \\
Groot finansiële aansporings & 6,88 & \\
\hline Groot finansiële aansporings & 6,88 & $0,32^{*}$ \\
Klein finansiële aansporings & 6,56 & \\
\hline $\mathrm{p}<0,01$ & &
\end{tabular}

Uit Tabel 7 blyk dit dat persone met geen finansiële aansporings ' $n$ beduidend hoër mate van doelwitaanvaarding as persone met onderskeidelik klein en groot finansiële aansporings toon. Groot finansiële aansporings het wel tot 'n beduidend hoër mate van doelwitaanvaarding as klein finansiële aansporings gelei. 
Die eersgenoemde bevinding verskaf dus geen ondersteuning aan die siening van Locke (1968) nie. Hy is van mening dat finansiële aansporings tot ' $n$ toename in doelwitaanvaarding kan lei. Gedeeltelike ondersteuning ten opsigte van hierdie siening van Locke (1968) word wel deur die tweede bevinding verskaf.

\section{SAMEVATTING}

In hierdie studie is probeer bepaal watter invloed aspekte van doelwitstelling soos doelwitmoeilikheidsgraad, doelwitspesifiekheidsgraad en finansiële aansporings op veranderlikes soos prestasie en doelwitaanvaarding het. Hierdie verskillende fasette van doelwitte en aksieplanne om hierdie doelwitte te bereik, vorm die kern van die doelwitbestuursproses. Steers en Porter (1974) is dan ook van mening dat die daarstelling van spesifieke prestasiedoelwitte en ook persoonlike ontwikkelingsdoelwitte 'n noodsaaklike vereiste vir die instelling van 'n doelwitbestuursprogram is.

Alhoewel daar in die studie hoofsaaklik op die verband tussen doelwitstelling en prestasie gekonsentreer is, blyk dit dat doelwitstelling ook 'n wesenlike invloed op ander aspekte van organisatoriese gedrag soos werkstevredenheid kan hê (Locke, Cartledge en Knerr, 1970; London en Oldham, 1976). Verskeie navorsers beweer verder dat 'n koppeling tussen die doelwitstellingsteorie en die verwagtingsteorie wel moontlik is (Steers en Porter, 1974; Mento, et al., 1980) terwyl Miner (1980) daarop wys dat daar ook verskille tussen hierdie twee teorieë bestaan wat blykbaar nie op 'n bevredigende wyse uit die weg geruim kan word nie.

Daar is dus in hierdie ondersoek voortgebou op die basiese navorsing wat alreeds oor doelwitstelling gedoen is. Sekere aspekte van die doelwitstellingsteorie van Locke (1968) word egter deur die bevindings van hierdie studie bevraagteken. Gevolglik word die volgende aanbevelings vir verdere navorsing op hierdie terrein gemaak:

- $\quad$ Die invloed van doelwitmoeilikheidsgraad op prestasie moet oor 'n redelike lang tydperk bestudeer word. Die motiveringskrag van baie moeilike doelwitte oor 'n lang tydperk word dan ook deur Miner (1980) bevraagteken.

- Die aspek van doelwitspesifiekheid benodig verdere navorsing, gesien in die lig van die bevindings van hierdie studie. Die invloed wat die twee mees algemene nie-spesifieke 
doelwitte, naamlik (a) "doen julle beste" en (b) "werk totdat julle gevra word om te stop", op prestasie kan hê, moet veral aandag geniet.

- Dit is moontlik dat die invloed van groot finansiële aansporings op prestasie nie deur die aansporing self nie, maar deur die kompetisie wat as gevolg van die aansporing ontstaan het, veroorsaak is. Daar word dus aanbeveel dat die invloed wat finansiële aansporings en kompetisie op prestasie kan hê, onafhanklik van mekaar bepaal word. Die motiveringskrag van kompetisie en finansiële aansporings oor 'n redelike lang tydperk regverdig ook verdere navorsing.

\section{OPSOMMING}

Ofskoon die meeste navorsing Locke se doelwitstellingsteorie ondersteun, is bepaalde afwykings teengekom wat nie op 'n bevredigende wyse verklaar kan word nie. Die resultate van hierdie studie dui daarop dat 'n toename in doelwitmoeilikheidsgraad nie altyd tot " $n$ ooreenstemmende toename in prestasie lei nie. Hierdie resultaat kon ook nie op grond van 'n gebrek aan doelwitaanvaarding verklaar word nie. Daar is voorts gevind dat die wyse waarop 'n nie-spesifieke doelwit gestel word, 'n beduidende invloed op prestasie kan hê. Finansiële aansporings blyk ook 'n onafhanklike invloed op prestasie te hê. Bepaalde aspekte van Locke se teorie word dus deur bogenoem-de resultate bevraagteken. Aanbevelings vir verdere navorsing word ten slotte gedoen.

\section{VERWYSINGS}

Du Toit, J.M. Statistiese metodes. Stellenbosch: Kosmo-Uitgewery, 1975.

Frost, P.J. \& Mahoney, T.A. Goal setting and the task process: I. An interactive influence on individual performance. Organizational behavior and Human Performance, 1976, 17, 328-350.

Latham, G.P., \& Yukl, G.A. A review of research on the application of goal setting in organizations. Academy of Management Journal, 1975, 18, 824-845.

Locke, E.A. Toward a theory of task motivation and incentives. Organizational behavior and Human Performance, 1968, 3, 157-189.

Locke, E.A. \& Bryan, J.F. Performance goals as determinants of level of performance and boredom. Journal of Applied Psychology, 1967, 51, 120-130.

Locke, E.A., Bryan, J.F. \& Kendall, L.M. Goals and intentions as mediators of the effects of monetary incentives on behavior. Journal of Applied Psychology, 1968, 52, 104,121.

Locke, E.A., Cartledge, N., \& Knerr, C.S. Studies of the relationship between satisfaction, goal setting, and performance. Organizational behavior and Human Performance, 1970, 5, 135-158. 
Locke, E.A., Shaw, K.N., Saari, L.M. \& Latham, G.P. Goal setting and task performance: 1969-1980. Psychological Bulletin, 1981, 90, 125-152.

London, M. \& Oldham, G.R. Effects of varying goal types and incentive systems on performance and satisfaction. Academy of Management Journal, 1976, 19, 537-546.

Louw, J.G.A. 'n Ondersoek na die invloed van doelwitstelling op prestasie. Stellenbosch: M.Comm-werkstuk, Universiteit van Stellenbosch, 1983.

Luthans, F. Organizational behavior. 3rd Ed. New York: McGraw-Hill, 1981.

Mento, A.J., Cartledge, N.D. \& Locke, E.A. Maryland vs. Michigan vs. Minnesota: Another look at the relationship of expectancy and goal difficulty to task performance. Organizational behavior and Human Performance, 1980, 25, 419-440.

Miner, J.B. Theories of organizational behavior. Hinsdale: The Dryden Press, 1980.

Pritchard, R.D., \& Curts, M.I. The influence of goal setting and financial incentives on task performance. Organizational behavior and Human Performance, 1973, 10, 175-183.

Rosswork, S.G. Goal setting: The effects on an academic task with varying magnitudes of incentive. Journal of Educational Psychology, 1977, 69, 710-715.

Steers, R.M., \& Porter, L.W. The role of task-goal attributes in employee performance. Psychological Bulletin, 1974, 81, 434-452. 